\title{
Employment trends in Latin America and the Caribbean during the 1990s
}

\section{Jürgen Weller}

Economic Affairs Officer, The economic reforms applied in the region during the $1980 \mathrm{~s}$ Economic Development Division, and 1990s created expectations, for which there was theoEconomic Commission for Latin America and the Caribbean (ECLAC) jweller@eclac.cl retical justification, of strong job creation and greater equity in the labour market. This article analyses developments in the quantity and characteristics of employment during the 1990s. It concludes that today's labour market problems are due to insufficient economic growth and to less intensive use of labour, resulting mainly from changes in tradable goods-producing activities. Modernization of production methods in companies and sectoral restructuring that increased the weight of tertiary activities contributed to segmentation of the labour market on the basis of people's level of education, as the demand for labour shifted towards those who had passed through intermediate and higher education. People with less formal education had less access to wage employment and wage differences between skilled and unskilled workers widened. At the same time, wage differences between microenterprises and larger ones increased and, with employment relationships becoming more flexible as well, employment quality indicators tended to worsen. All these tendencies were contrary to what had been expected from the reforms. Sectoral restructuring of employment helped trigger a trend towards increasing heterogeneity in the labour market, and this took a variety of forms: substantial and simultaneous job creation at the top and bottom of the employment structure, a widening of the gap between formal and informal activities, differentiation of working conditions within medium-sized and large firms, and internal differentiation among microenterprises and own-account workers. 


\section{Introduction}

Developments in the labour market between 1950 and 1980 were characterized by a process of social participation and exclusion: while a growing proportion of the economically active population succeeded in participating in dynamic activities, large numbers of people who left the agricultural sector as a result of interlinked processes of attraction and expulsion -and of whom many migrated to the big cities- could only find employment in low-productivity, low-paid activities (PREALC, 1991, pp. 9-14). There thus arose a consensus, reached from a variety of theoretical positions, to the effect that even though open unemployment rates were fairly low on average, there were still severe labour market problems in the region. The main one identified was underemployment (visible and invisible), which affected large groups of people in small-scale farming and the urban informal sector. During the crisis of the 1980s, the problems of the labour market worsened as the ability of the formal sectors to generate productive employment declined, with most new jobs being created in the informal sector. At the same time, labour productivity and real wages fell.

The idea behind the economic reforms undertaken in the 1980s and 1990s was not just to achieve greater macroeconomic stability and higher rates of output growth, but also to solve the structural problems affecting the region's labour markets. The starting assumption was that underutilization of the labour force, at a time when "inward" growth strategies were the norm, was mainly due to distortions that had arisen in the different markets for goods and factors. The first of these distortions was taken to be an anti-export bias that favoured import substitution activities and the production of non-tradable goods and services at the expense of exports, which were more labour-intensive. Secondly, it was argued that distortions in the labour

This article forms part of the research project "Growth, Employment, and Equity. The Impact of the Economic Reforms in Latin America and the Caribbean" conducted by ECLAC and researchers in nine countries of the region and financed by the Governments of the Netherlands and Sweden, the Canadian International Development Research Centre and the Ford Foundation. and capital markets had lowered the cost of capital and raised the cost of labour, and that this had had a negative impact on the demand for labour. Lastly, it was considered that the urban bias of this policy had relegated agricultural activities, which tend to be more labour-intensive, to a position of secondary importance. Removing these distortions from goods and factor markets would involve reallocating resources to activities that produced exportable goods and to technologies that were more labour-intensive, whereupon the demand for labour would increase. Besides this the reforms, taken all together, would have a positive effect on economic growth, an essential variable for increased job creation.

Because of the relative abundance of low-skilled workers, the bulk of the additional demand would be for labour of this type. This would increase the relative wages of low-skilled workers, which would have positive effects on distribution. Another positive development in this respect would be the strengthening of small and medium-sized enterprises, as it was argued that the existing distortions had given big firms an unfair advantage over small ones. Lastly, the abolition of certain labour regulations and measures to reduce the cost of others would be conducive to the formalization of employment conditions and would reduce the relative weight of the informal sector in employment.

During the 1980s and 1990s, reforms designed to remove distortions in the different markets of the region made considerable progress (Morley, Machado and Pettinato, 1999). So far, evaluations of developments in the region's labour markets during the 1990s have judged the results of these reforms to be disappointing. ${ }^{1}$ A fairly common conclusion is that the labour market situation is the biggest problem facing the Latin American and Caribbean countries, and the region is often said to be experiencing "jobless growth".

\footnotetext{
${ }^{1}$ See ECLAC (1997), Thomas (1997), Lora and Olivera (1998) and Weeks (1999). ILo publications also stress the weakness of job creation, in terms of both quantity and quality, but note that the countries which implemented the reforms earliest have seen better results; see, for example, ILO (1999b).
} 


\section{II}

\section{General developments in labour markets during the 1990s}

This section will describe some general tendencies in the region's labour markets during the 1990s, after which it will detail some aspects that reflect the high degree of heterogeneity between countries. The objective is to evaluate the labour market in relation to the expectations created by the economic reforms and the needs of the region's households.

Figure 1 shows how some labour market indicators have evolved for the region as a whole. The values given are medians, to prevent the biggest countries (in the case of weighted averages) or certain extreme situations (in the case of simple averages) having a disproportionate influence on the data. The indicators are the total participation rate (TPR), the employment rate (ER), the real average wage in the formal sector (RAW) and the real minimum wage (RMW). The number of countries for which the relevant information is available is given in brackets.

The total participation rate shows an upward trend, although not without fluctuations. By contrast, the employment rate, after rising in the early 1990s, fell markedly over the following years, and the subsequent rise through 1997 and 1998 was not enough to close

FIGURE 1

Latin America and the Caribbean: Employment and wages, $1990 \mathrm{~s}^{\mathrm{a}}$

(Medians)

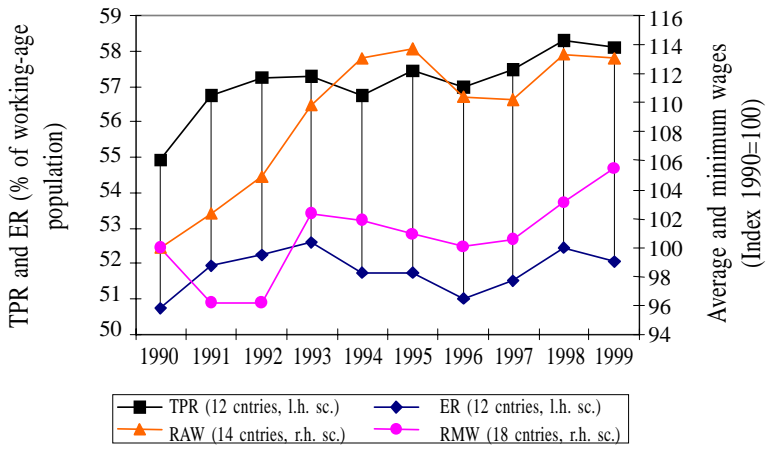

Source: ECLAC (2000b) and official data from the countries.

a In most of the countries the participation and employment rates are for urban areas. the gap with the supply of labour, the result being higher unemployment rates (black lines on the chart). Furthermore, the new jobs were created to a disproportionate extent in low-productivity activities. ${ }^{2}$ The trend in wages was somewhat more favourable, as they rose during the first five years of the decade. Subsequently, though, they stagnated owing to a high degree of economic volatility, annual growth being just over $1 \%$, which was higher than the rate seen in the previous decade, but not by much. Thus, by the end of the 1990s a number of countries had still not managed to return to the levels obtaining in 1980 (ECLAC, 2000b, table VI.4).

As regards minimum wages, the cautious policies which had been applied in the previous decade were maintained; only during the later years were there some real increases, giving an annual rise of around half a per cent on average over the decade.

How does job creation in the 1990s look by historical standards? Table 1 shows that the rate of employment generation increased between the 1950s and the 1970s, then fell in subsequent decades. The employment-elasticity of output in the 1990s does not differ greatly from the regional average for the whole period 1950-1997. At this level of aggregation, no fundamental shift has been seen either towards greater relative use of the workforce by comparison with the long-term trends of previous decades (as had been argued in favour of the reforms) or towards lower labour-intensiveness (which was a criticism in the 1990s), and there is no justification for talking about jobless growth. Thus, the main reason (although not the only one) for the rise in open unemployment during the 1990s would seem to be the weakness of economic growth, which was not sufficient to absorb the growing supply of labour.

In simplified terms, the region's labour markets can be analysed in two segments, the first corresponding more to the dynamic of labour demand and the sec-

2 The median figures for 12 countries have the share of urban employment provided by the informal sector rising from $43.5 \%$ to 47.9\% between 1990 and 1998 (author's calculation based on ILO, 1999a). 
TABLE 1

Latin America and the Caribbean: Annual growth in output and employment and the employment elasticity of output, 1950-1999

\begin{tabular}{|c|c|c|c|c|c|}
\hline Period & $\begin{array}{l}\text { Economic } \\
\text { growth }\end{array}$ & $\begin{array}{l}\text { Employment } \\
\text { growth }\end{array}$ & $\begin{array}{c}\text { Employment elasticity } \\
\text { of output }\end{array}$ & $\begin{array}{c}\text { Growth in wage } \\
\text { employment }\end{array}$ & $\begin{array}{l}\text { Wage employment } \\
\text { elasticity of output }\end{array}$ \\
\hline $1950 \mathrm{~s}$ & 5.1 & 1.9 & 0.4 & 2.5 & 0.5 \\
\hline $1960 \mathrm{~s}$ & 5.7 & 2.3 & 0.4 & 2.7 & 0.5 \\
\hline $1970 \mathrm{~s}$ & 5.6 & 3.8 & 0.7 & 4.7 & 0.8 \\
\hline $1980 \mathrm{~s}$ & 1.2 & 2.9 & 2.6 & 2.4 & 2.0 \\
\hline $1990 \mathrm{~s}^{\mathrm{a}}$ & 3.8 & 2.2 & 0.6 & 2.2 & 0.6 \\
\hline 1950 s to $1990 \mathrm{~s}$ & 4.3 & 2.7 & 0.6 & 3.0 & 0.7 \\
\hline
\end{tabular}

Source: Prepared by the author on the basis of information from ECLAC and the International Labour Organization (ILO).

a $1990-1997$.

ond to the dynamic of supply. Because of this second dynamic, which is of great structural importance in countries that lack systems of unemployment benefit, in the long term -and when comparisons are made between countries- job creation is closely correlated with movements in supply. This is particularly true of overall employment. Thus, the employment growth shown in table 1 -rising up until the 1970 s, declining thereafter- mainly reflects developments in supply, and particularly in its most important component, the demographic one, rather than differences in the use made of the labour factor by growth models of different kinds.

Simplifying once again, waged employment can be used as a proxy for developments in the segment determined mainly by demand, as it reflects the willingness of companies and the public sector to "pay a price", and own-account working can be used in the same way for the segment determined mainly by supply, as these are the main occupational categories of the respective segments. By historical standards, growth in wage employment was relatively weak (table 1). Whereas from the 1950s to the 1970s wage employment grew more quickly than employment overall, and its share of total employment rose, in the 1990s employment in this category only grew at the same rate as overall employment. ${ }^{3}$ It fared worse only in the 1980 s, when its share of total employment fell. The pressure of supply, of course, can also influence the generation of certain kinds of wage employment, particularly in

\footnotetext{
${ }^{3}$ Relative growth in wage employment would be weaker if the information for 1998 and 1999 were included, as in both years wage employment grew more slowly than the other employment categories taken together (see the relevant volumes of the ECLAC Economic Survey of Latin America and the Caribbean).
}

microenterprises ${ }^{4}$ just as there is own-account employment that reflects preferences and opportunities -in respect of income or other aspects- more than the mere necessity of generating minimum incomes for survival, a necessity which is characteristic of those working in the segment mainly determined by the supply situation.

When the main labour market trends of the 1990s are analysed in greater detail, it is found that the characteristics of the labour supply in that decade did not differ sharply from previous tendencies. The increase in its demographic component continued to tail off ${ }^{5}$ and the participation rate continued to rise, owing to the increasing numbers of women entering labour markets. ${ }^{6}$ Thus, the total labour supply continued to grow by more than its demographic component. As for the qualitative aspects, we find that the two components of the labour supply that are generally deemed essential for the development of human resources -formal education and work experience- developed positively. On the one hand, enrolment in secondary and tertiary education increased and, as young people with more years of formal education entered the labour market, the average educational level of the workforce rose, although with major quantitative and qualitative shortcomings

\footnotetext{
${ }^{4}$ The fact that job creation in the 1980s was low in relative terms, but higher than in the 1990s in absolute terms, shows that in situations of economic crisis too waged employment reflects the pressure of supply to a great extent. In fact, most waged employment was generated in microenterprises.

${ }^{5}$ Annual growth in the working-age population fell from $2.5 \%$ in the early 1980 s to $2.0 \%$ in the late 1990 s (author's calculation based on ECLAC/CELADE, 1999).

${ }^{6}$ See ECLAC (2000b, statistical annex) for the way labour market participation developed differently by sex.
} 
TABLE 2

Latin America and the Caribbean (17 countries): Annual employment growth by occupational category and contribution of categories to job creation, 1990-1997

\begin{tabular}{|c|c|c|c|c|}
\hline \multirow[t]{2}{*}{ Occupational category ${ }^{a}$} & \multicolumn{2}{|c|}{ Annual growth } & \multicolumn{2}{|c|}{ Contribution to new jobs } \\
\hline & Weighted average & Median & Weighted average & Median ${ }^{b}$ \\
\hline Wage earners, total (17) & 2.2 & 2.7 & 51.8 & 62.1 \\
\hline Private-sector wage earners (13) & 2.2 & 3.2 & 49.7 & 52.6 \\
\hline Public-sector wage earners (13) & 0.7 & 0.6 & 2.0 & 2.5 \\
\hline Own-account workers (17) & 2.8 & 3.1 & 35.9 & 34.2 \\
\hline Domestic service (13) & 3.9 & 3.5 & 9.9 & 3.9 \\
\hline Unpaid workers (15) & 0.4 & -1.9 & 1.7 & -0.5 \\
\hline Other categories (17) & 0.4 & 0.5 & 0.6 & 2.4 \\
\hline Total (17) & 2.2 & 3.4 & 100.0 & 100.0 \\
\hline
\end{tabular}

Source: Prepared by the author on the basis of household surveys from each country.

a The number of countries with information available is shown in brackets.

b The sum of the contributions does not necessarily total 100 .

(Duryea and Székely, 1998). On the other hand, the relative reduction in the size of the younger cohorts within the working-age population translated into a rise in average levels of work experience. In conclusion, most of the main quantitative and qualitative features of the labour supply were determined by long-term tendencies, with no sign of changes occurring in reaction to recent events such as the economic reforms. The only indicator that can reflect short-term reactions -and in fact does so throughout the cycle- is the participation rate, the trend in which, however, does not show any kind of abrupt change in direction.

The relative weakness of the demand for labour can be appreciated from table 2, which breaks down employment growth over the period 1990-1997 into the different occupational categories for the region as a whole.

Across the region, employment grew at an annual rate of $2.2 \% .{ }^{7}$ Employment in certain categories where working conditions and earnings are generally poor, such as own-account work and domestic service, grew by more than waged employment. Among wage earners, public-sector employment grew by less than total employment, owing to privatization and more restrictive fiscal policies. The number of unpaid family workers remained stable, which meant that their relative weight in the employment structure continued its longterm decline, mainly owing to the relative contraction

\footnotetext{
7 The $2.9 \%$ annual employment growth cited in other publications for the same period (ILO, 1998b; ECLAC, 2000a, p. 75) is for nonagricultural employment only.
}

of the family farming sector. Wage earners accounted for around half of all new employment (somewhat more in the median) and own-account workers for another third. Figure 2 shows the link between changes in the economic growth rate and changes in wage employment and wages, for four countries. ${ }^{8}$

Developments at the sectoral level were an important factor in accounting for both the quantity and the characteristics of job creation. During the 1990s the long-term tendencies for employment to fall in the primary sector and grow in the tertiary sector continued, while the relative expansion of employment in the secondary sector seems to have come to an end (table 3).

Between 1990 and 1997, manufacturing employment grew at an annual rate of $1.3 \%$. In the mediumsized and large countries, stagnation or even contraction of manufacturing employment in Argentina, Brazil and Colombia contrasts with substantial growth in Mexico. Agricultural employment declined even in absolute terms, so that the existing downward trend in the relative employment share provided by this sector intensified.

Construction, which is very labour-intensive and highly sensitive to the economic cycle, accounted for almost $10 \%$ of all new employment in the region. It was in the different branches of the tertiary sector, however, that the most dynamic developments were seen in terms of job creation. On the one hand, particularly

\footnotetext{
${ }^{8}$ Econometric estimates carried out as part of the project confirmed the importance of economic growth for job creation; see Weller (2000, chapter 4). See also Lora and Olivera (1998).
} 
FIGURE 2

\section{Argentina, Brazil, Chile and Mexico: Growth in wage employment and real wages in the formal sector}

Argentina, 1991-1997

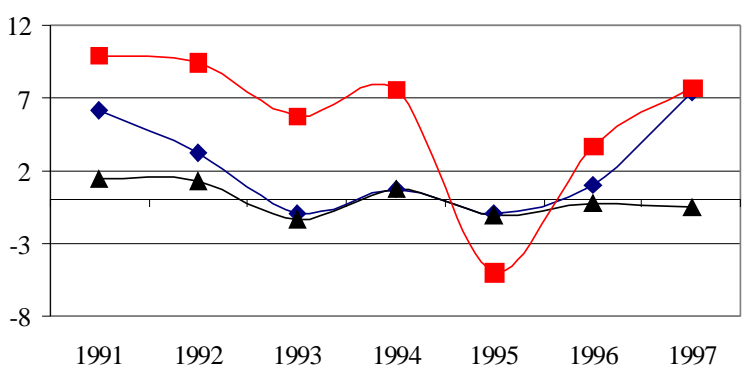

Wage employment $\rightarrow$ Wage $\rightarrow$ GDP

Chile, 1987-1997

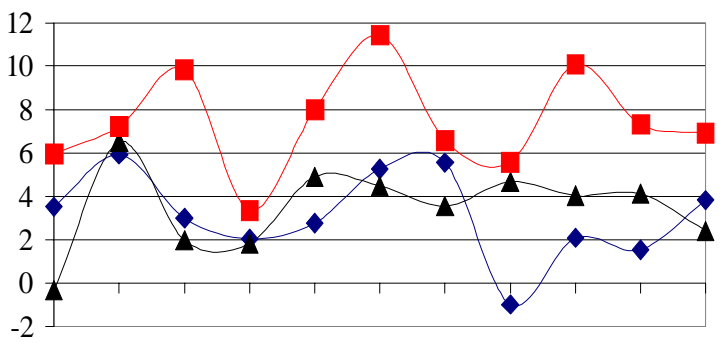

19871988198919901991199219931994199519961997

Wage employment $\leftarrow$ Wage $\leftarrow$ - GDP

Source: Prepared by the author on the basis of ECLAC information.

strong growth occurred in some areas associated with the transformation of the region's economies, particularly financial services, insurance, business services and real estate and basic services (electricity, gas and water; transport, storage and communications). On the other hand, the branch comprising trade, restaurants and hotels contains both activities that were very dynamic during the 1990s (large stores and supermarkets, foreign trade, tourism) and typical informal trading. A high degree of heterogeneity also characterizes social, community and personal services. Across the region, the latter two branches accounted for around $70 \%$ of the jobs created in the 1990s.

An important factor behind employment trends was the fairly general rise in female participation in the labour market (see the last column of table 3 ). This rise occurred in sectors with a traditionally high level of female involvement (services, trade and, to a lesser extent, manufacturing industry) but also in sectors
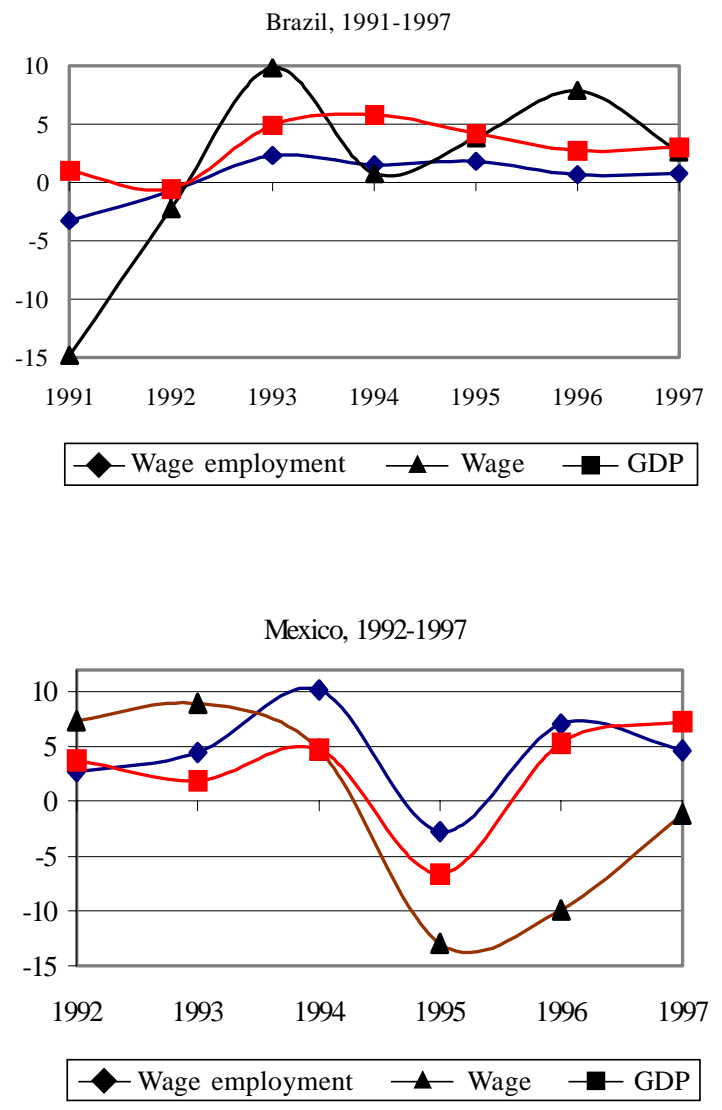

where this involvement is generally low. Furthermore, it was seen both in branches that did not generate strong employment growth in the 1990s and in the sectors that accounted for the bulk of such growth. The only exception was basic services, owing to the large rise in employment in transport services, where most jobs are held by men.

The new employment created in the 1990s has hastened the tendency, dating from previous decades, for the importance of the tertiary sector in the employment structure to increase. Towards the end of the decade, tertiary activities accounted for over $50 \%$ of employment in 12 of the 14 countries for which nationwide information is available; in three countries, the figure was over $60 \%$. In 1997, in the region as a whole, $54.9 \%$ of those in work were employed in tertiary activities. ${ }^{9}$

\footnotetext{
${ }^{9}$ Includes basic services.
} 
TABLE 3

Latin America and the Caribbean (17 countries): Growth and contribution to new employment by branch of activity, 1990s

(Percentages)

\begin{tabular}{|c|c|c|c|c|c|c|}
\hline \multirow[t]{3}{*}{ Branch of activity ${ }^{a}$} & \multicolumn{3}{|c|}{ Annual growth } & \multicolumn{2}{|c|}{$\begin{array}{l}\text { Contribution to new } \\
\text { employment }\end{array}$} & \multirow{3}{*}{$\begin{array}{c}\text { Change in } \\
\text { female } \\
\text { employment } \\
\text { share }^{\mathrm{d}}\end{array}$} \\
\hline & \multirow{2}{*}{$\begin{array}{l}\text { Value } \\
\text { added }^{\mathrm{b}}\end{array}$} & \multicolumn{2}{|c|}{ Employment } & \multirow{2}{*}{$\begin{array}{c}\text { Weighted } \\
\text { average }\end{array}$} & \multirow[t]{2}{*}{ Median $^{c}$} & \\
\hline & & $\begin{array}{l}\text { Weighted } \\
\text { average }\end{array}$ & Median & & & \\
\hline Agriculture (13) & 2.5 & -0.6 & -1.2 & -7.0 & -6.0 & 0.9 \\
\hline Manufacturing industry (17) & 3.5 & 1.3 & 1.3 & 8.7 & 6.8 & 1.6 \\
\hline Construction (17) & 4.2 & 3.0 & 4.2 & 8.6 & 8.6 & 0.3 \\
\hline Trade, restaurants and hotels (17) & 3.8 & 4.0 & 5.7 & 32.3 & 34.2 & 0.5 \\
\hline Financial services ${ }^{\mathrm{e}}(15)$ & 3.4 & 6.6 & 7.8 & 10.8 & 11.0 & 2.6 \\
\hline Basic services $^{f}(17)$ & 5.8 & 4.8 & 4.8 & 12.6 & 7.6 & -1.1 \\
\hline Social, community and personal services (17) & 2.2 & 2.9 & 2.8 & 37.2 & 31.8 & 0.9 \\
\hline Others (17) & $\ldots$ & -3.0 & -2.7 & -2.9 & -0.1 & n.d. \\
\hline Total (17) & 3.8 & 2.2 & 3.4 & 100.0 & 100.0 & 1.5 \\
\hline
\end{tabular}

Source: Prepared by the author on the basis of official figures from the countries and data from ECLAC and ILO (1998a).

a The number of countries for which information is available is given in brackets.

b Figures are for 31 countries in the region; the 17 countries for which information was available on employment growth accounted for $98.3 \%$ of regional GDP in 1995 .

c The different contributions do not necessarily add up to 100 .

d In percentage points; median for 13 countries.

e Includes financial services, insurance, business services and real estate.

f Includes electricity, gas and water, and communications, transport and storage.

The decline in agricultural employment accelerated as well. In previous decades this had grown more slowly than employment generally, but in the 1990s it actually declined in absolute terms in 8 of the 13 countries for which information is available, and in the region as a whole, so that the share of the sector in regional employment fell to $23.6 \%$. Towards the end of the decade, manufacturing employment accounted for only $13.5 \%$ of total employment in the region, while construction contributed a further $6 \%$.

Developments in employment were matched by developments in labour productivity. After falling sharply in the previous decade, average labour productivity rose again in the 1990s, although as of 1997 it had not returned to the 1980 level. ${ }^{10}$ If growth rates for employment and value added are compared at the sectoral level (table 3), it is found that in the sectors mainly encompassing tradable goods production activities -the primary and secondary sectors- productivity rose, but employment barely did so, while in the

${ }^{10}$ In the two-year period 1998-1999 average labour productivity fell again. tertiary sector, consisting mainly of non-tradable activities, employment rose, but not productivity. This is due to the fact that the increased involvement of the region in global markets was not based, as had been expected, on factor use reflecting its relative abundance of labour and capital. Many increasingly integrated markets are governed by standards of competitiveness whose parameters are largely defined by labour-saving technologies. Meanwhile, in the case of products for which competitiveness is "basic factor driven", to use the terminology of Porter (1990), and for which it is very important to have a large, relatively low-skilled workforce available, there are apparently other regions which have the edge over Latin America. ${ }^{11}$ Develop-

\footnotetext{
${ }^{11}$ See Wood (1997). Some countries in the north of the region (Mexico and countries in Central America and the Caribbean) have apparently escaped, at least in part, from a situation in which competitive pressures come both from above and below. Although the tendencies referred to have not been absent there, increasing integration with the North American market (as a result of geographical proximity and special trading conditions) has enabled labourintensive activities to expand (inbond assembly plants, certain agricultural products).
} 
ments in sectoral productivity are also indicative of a poor capacity to generate productive employment, since they suggest that many of the new jobs have arisen in low-productivity activities in the tertiary sector. ${ }^{12}$

Given this situation in the region as a whole, note should be taken of the great diversity of the results obtained for the different countries making it up. Table 4 shows these results for 17 countries, summarizing the changes in five variables: the unemployment rate, the employment rate, the average real wage in the formal sector, labour productivity and, lastly, the relationship between waged employment growth and total employment (as an indicator of the relative strength of demand for labour).

Large differences are seen between the countries, with a relatively favourable performance in Chile, the Dominican Republic, El Salvador and Panama and, to a lesser extent, in Costa Rica, Mexico, Peru and Uruguay, and an unsatisfactory performance in Argentina, Brazil, Colombia, Paraguay and Venezuela. ${ }^{13}$ Economic growth played a very important role in these results, as can be seen in figure 3, which is based on an index designed to quantify the data for the 17 countries in the 1990s in relation to the first four variables of table 4. ${ }^{14}$ Indices were calculated for each variable and a value of between 0 and 1 was assigned to them for the different countries, depending on the gap between them and the best-performing (1) and worst-performing (0) country. An average of these five indices was then taken in order to calculate the labour market performance index.

The countries that do not show this close correlation between economic growth and the labour market performance index are, on the one hand, Argentina and Peru, where the reforms implemented with great speed at the beginning of the decade had a negative impact on several aspects of the labour market and, on the other, Jamaica, where the result has been better than expected, thanks to relatively strong private-sector wage employ-

12 Before 1980 the tertiary sector was the biggest source of new jobs, but in a context of rising labour productivity. According to ILO calculations, in the 1990s six out of every 10 new jobs in urban areas were created in the informal sector (ILO, 1999b).

${ }^{13}$ See ECLAC (2000b, chapter 6) for details of changes in the level of unemployment, average wages and minimum wages in the individual countries.

${ }^{14}$ Labour productivity was excluded to avoid the apparent correlation that would arise if the economic growth variable were incorporated into the values for both axes of the chart. Consequently, the relative positions of the countries are not exactly the same as shown in table 4.
FIGURE 3

Latin America and the Caribbean (17 countries): Economic growth and labour market performance, 1990s

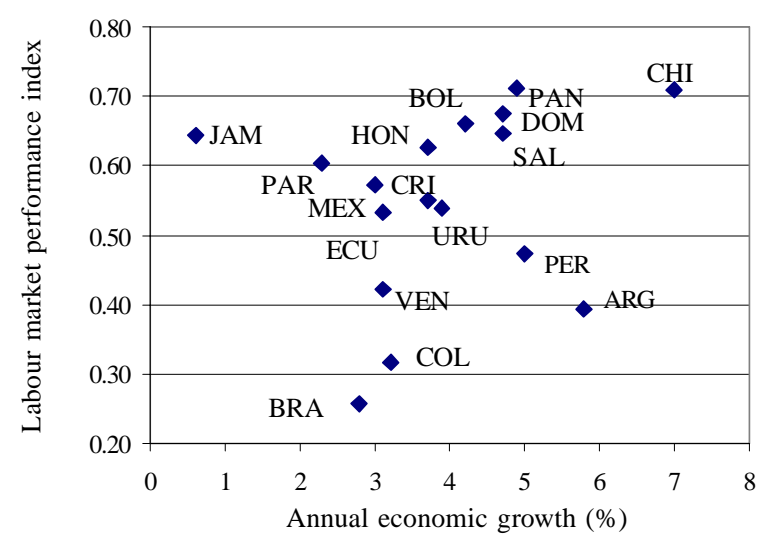

Source: Prepared by the author on the basis of ECLAC information and official data from the countries.

ment growth in tertiary activities, higher real wages and the stabilization of unemployment, albeit at a high level.

Some of the countries that applied the reforms earliest (Bolivia, Chile, Costa Rica) are among the countries that have a relatively good labour market track record, although without departing from the trend. This agrees with the results of econometric exercises indicating that the economic reforms had a small positive impact on growth, something that would in turn have had a favourable impact on employment. ${ }^{15}$ Against all expectations, however, the reforms would appear to have reduced the labour-intensiveness of economic growth, with negative consequences for job creation. ${ }^{16}$ This process was not a transitory one, as this reduction in labour-intensiveness seems to have been maintained over the longer term. In the aggregate, trade liberalization has had a negative impact on labour-intensiveness. Lastly, a positive correlation was detected between the real exchange rate and labour-intensiveness and this, given the tendencies towards appreciation seen in the region over the greater part of the 1990s, has come to be viewed as another adverse influence on the demand for labour.

Thus, the apparent contradiction between the negative impact of the reforms on employment, as identified in most studies, and the more favourable developments detected by ILO (1999b) in the labour markets of the countries that reformed early, can be accounted for by the better economic growth in these countries, while

\footnotetext{
${ }^{15}$ See Stallings and Peres (2000), also IDB (1997).

${ }^{16}$ See Weller (2000, section 4.2).
} 
TABLE 4

Latin America and the Caribbean (17 countries): Changes in labour market indicators in the $1990 \mathrm{~s}^{\mathrm{a}}$

\begin{tabular}{|c|c|c|c|c|c|}
\hline Country and threshold year for reforms & Unemployment & Employment level & Waged employment & Real wages & Labour productivity \\
\hline Argentina, 1990 & - & - & + & $=$ & + \\
\hline Bolivia, 1986 & + & + & - & + & - \\
\hline Brazil, 1989 & - & - & $=$ & + & + \\
\hline Chile, 1974 & + & + & + & + & + \\
\hline Colombia, 1992 & - & $=$ & - & + & + \\
\hline Costa Rica, 1987 & $=$ & + & $=$ & + & + \\
\hline Dominican Republic, 1991 & - & + & - & + & $=$ \\
\hline Ecuador, 1992 & + & + & + & $=$ & + \\
\hline El Salvador, 1990 & + & + & $=$ & - & - \\
\hline Honduras, 1992 & $=$ & - & + & + & - \\
\hline Jamaica, 1991 & - & + & + & + & $=$ \\
\hline Mexico, 1989 & + & + & + & + & + \\
\hline Panama, n.a. & - & + & - & + & - \\
\hline Paraguay, 1990 & $=$ & + & - & + & + \\
\hline Peru, 1991 & + & $=$ & + & + & + \\
\hline Uruguay, 1979 & - & + & $=$ & + & + \\
\hline Venezuela, 1991 & - & + & - & - & - \\
\hline
\end{tabular}

Source: Prepared by the author.

a The threshold years for the reforms are the years in which the reform index, as calculated by Morley, Machado and Pettinato (1999), rose the most. Labour market performance was assessed on the basis of changes between the beginning of the 1990 s and 1998 (1997 in some cases). + means a positive change, - means a negative change, = no change or very small change. Column 1: Percentage change in the unemployment rate. Column 2: Change in the employment rate, in percentage points. Column 3: Growth in waged employment compared with overall employment growth. Column 4: Percentage change in the average real wage in the formal sector. Column 5: Percentage change in average labour productivity.

in the others the decline in labour-intensiveness led to more negative results.

In conclusion, it can be said that job creation in the 1990s was disappointing, both by comparison with the 1950s, 1960s and 1970s (relatively little creation of wage employment) and in relation to what was expected of the reforms in terms of the rate and sectoral composition of job creation and to the needs of households (rising unemployment being evidence of this), although with major differences between countries. The underlying reasons were weak economic growth and low demand for labour in branches producing tradable goods, in a context of integration with international markets. 


\section{III}

\section{The bias of labour demand}

As was seen earlier, one theoretical justification for the reforms was the argument that changes in the production structure and in the different sectors would foster demand for unskilled labour, owing to the relative abundance of this factor in the countries of the region, and that this in turn would be instrumental in reducing wage differences between high-skilled and low-skilled workers. These expectations seemed to be borne out in the 1980 s, when the gap between the average wages of people with a university education and those with primary education lessened in most of the countries of Latin America and the Caribbean (Psacharopoulos and Ng, 1992, p. 15).

A number of studies dealing with the case of Chile, however, have raised doubts as to whether these tendencies can continue beyond the reform stage in a context of greater economic growth. ${ }^{17}$ In fact, if the improved educational level of the working-age population is compared with that of people in work it is found that in most of the countries groups with medium-high (between 10 and 12 years of study) and high (13 years of study and over) levels of education saw their share in employment grow by more than the proportion of the whole working-age population they accounted for; the opposite occurred in the case of groups with lower levels of education (Weller, 2000, table 6.1). This differentiation in the employment structure by educational level appears to provide initial confirmation that during the 1990s the demand for labour was oriented towards skilled workers and not towards unskilled ones.

If this orientation exists, it should be reflected by differences between educational levels in the creation of wage and non-wage employment. Since wage employment gives the truest picture of the demand for labour, differences of this type would show that the higher growth in employment for skilled workers really was due to demand preferences. Figure 4 illustrates this aspect. It shows, for seven countries, the different proportions of new employment accounted for by waged and unwaged jobs in respect of three educational

${ }^{17}$ For the case of Chile in particular, Robbins (1994 and 1996) identified a tendency for wage differentials to rise.

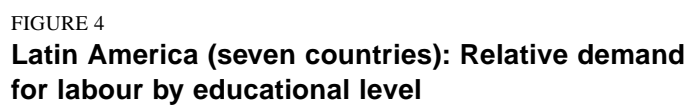

FIGURE 4 Latin America (seven countries): Relative demand for labour by educational level

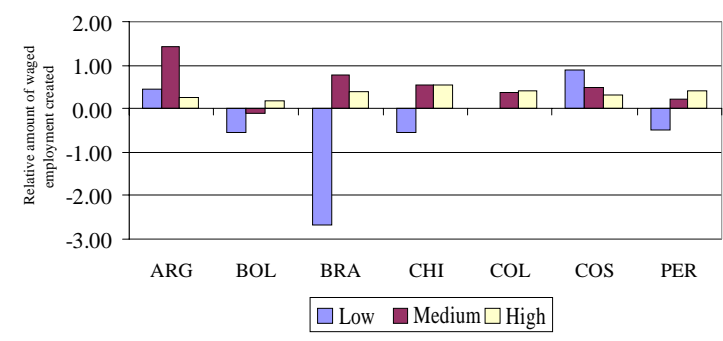

Source: Prepared by the author.

groups, divided, for reasons of standardization, by the share of the new employment taken by the entire educational group. This indicator can be interpreted as representing the relative demand from companies for the different educational groups in the workforce. A positive value means that wage employment accounted for more of the new employment taken up by the educational group concerned, while a negative value means that non-wage employment accounted for more.

As can be seen, in Bolivia, Brazil, Colombia, Chile and Peru there is a fairly strong positive correlation between educational level and the relative demand for labour by companies. The exceptions are Argentina and Costa Rica. In Argentina, the group with the lowest level of education saw a decline in the absolute numbers of both wage earners and unwaged workers, so the positive value does not mean that companies have a preference for this group of workers. Only in Costa Rica was there strong relative demand for workers in the lowest educational segment.

During the 1990s, segmentation of the labour market by educational level generally became more acute: while demand was skewed towards workers with more years of education, workers with less schooling had greater difficulty in finding wage employment and a higher proportion of them worked in non-wage occupations.

What is the source of this rising demand for highly skilled staff? To identify it, changes in wage employment were broken down with a view to distinguishing between the contribution made by changes within 
branches of activity on the one hand and, on the other, the contribution of changes between branches of activity (table 5). To this end, the following calculation was carried out in respect of people with a high level of education (13 years and over): ${ }^{18}$

$\Delta S=\sum_{i=1}^{n} \Delta A_{i} \bar{S}_{i}+\sum_{i=1}^{n} \Delta S_{i} \bar{A}_{i}$

for $i=1 \ldots ., n$ branches of activity

where:

$S=$ highly educated staff as a proportion of all those in wage employment

$S_{i}=$ proportion of highly educated staff in branch of activity i

$A_{i}=$ wage employment in branch $\mathrm{i}$ as a proportion of all wage employment

In the equation, the strokes indicate averages of the relevant values for the beginning and end years. Thus, the first term on the right-hand side of the equation captures the contribution of changes between branches (i.e., the differences in respect of wage employment growth), while the second term captures the contribution of changes within the branch (i.e., changes in the share of wage employment in that branch accounted for by highly qualified staff).

In the median for eight countries, the share of highly qualified staff in waged employment rose by 2.3 percentage points. As the first part of table 5 shows, the greatest contribution to this increase was made by changes within branches. ${ }^{19}$ Changes between branches, however, were also important: the shift in employment towards activities that use more highly skilled labour and a decline in the employment share of branches that, generally speaking, require lower skill levels.

\footnotetext{
${ }^{18}$ Adapted from Berman, Bound and Griliches (1994).

19 The median was chosen rather than the simple average to prevent atypical cases having too great an impact on the result.
}

TABLE 5

Latin America (eight countries): Contribution of changes within and between branches of activity to changes in the wage employment shares of educational groups, 1990s (Percentage points, medians ${ }^{a}$ )

\begin{tabular}{lll}
\hline & Within branch & Between branches \\
\hline
\end{tabular}

A. Wage earners with a high level of education (13 years and over)

Total

Agriculture

Manufacturing industry

Electricity, gas, water

Construction

Trade, hotels and restaurants

Transport and communications

Financial services, business services and others

Community services and others

$\begin{array}{lc}1.64 & 0.63 \\ 0.02 & -0.03 \\ 0.05 & -0.15 \\ 0.01 & -0.02 \\ 0.01 & -0.01 \\ 0.19 & 0.13 \\ 0.04 & 0.01 \\ 0.23 & 0.45 \\ 1.09 & 0.27\end{array}$

B. Wage earners with a low level of education (up to 8/9 years)

Total

Agriculture

Manufacturing industry

Electricity, gas, water

Construction

Trade, hotels and restaurants

Transport and communications

Financial services, business services and others

Community services and others

Source: Prepared by the author.

a A positive value represents a positive contribution to the employment share of the group concerned; a negative value represents a negative contribution.

b Sum of the two columns. 
As regards the contribution of the different branches to the increased employment of skilled workers, the negative impact of the changes between branches is not surprising, given the decline in the share of wage employment accounted for by manufacturing industry. Internal changes within the sector, however, did not contribute significantly to the demand for highly educated staff. This confirms the results of other studies which find that changes in production methods in this sector have not (yet) resulted in a major net shift towards higher skill levels. Although restructuring has often led to cuts in low-skilled staff, skilled jobs have also gone, for example, in research and development departments (see Katz, 2000). Thus, any rise in demand for skilled personnel resulting from the introduction of new technologies has been partially offset by the elimination of other highly skilled jobs. Consequently, internal changes in the sector contributed very little to the rise in the wage employment share of highly qualified personnel. Furthermore, because the decline in the sector's contribution to wage employment meant that employment opportunities for people in this group were lost, the transformation of manufacturing industry had a negative impact on the demand for their labour.

In tertiary activities, the most important sector in terms of job creation, the great bulk of new wage employment was for people with medium-high and high educational levels. Figure 5, which summarizes the characteristics of new wage-paying jobs in the tertiary sector, shows the predominance of intermediate and high education requirements.

For people in the highest category, most jobs were in financial services, insurance, real estate and business services and community, social and personal services. By contrast, in the area of trade, restaurants and hotels and in basic services (mainly because of transport) most demand was for people with an intermediate level of education. Employment for less well qualified people was created in the branches of trade, restaurants and hotels and community, social and personal services. Thus, it was in these last two branches that the greatest diversity of wage employment was seen, with new jobs being created across the entire educational spectrum. By contrast, the two branches most closely associated with the modernization process - basic services on the one hand, and financial services, insurance, real estate and business services on the other- created very few jobs for less well educated people, as most new employment was for those with an intermediate level of education, in the first case, and a high level, in the second.
FIGURE 5

Latin America (eight countries): Composition of new waged jobs in tertiary activities by educational level and branch

(Simple averages) $^{\mathrm{a}}$

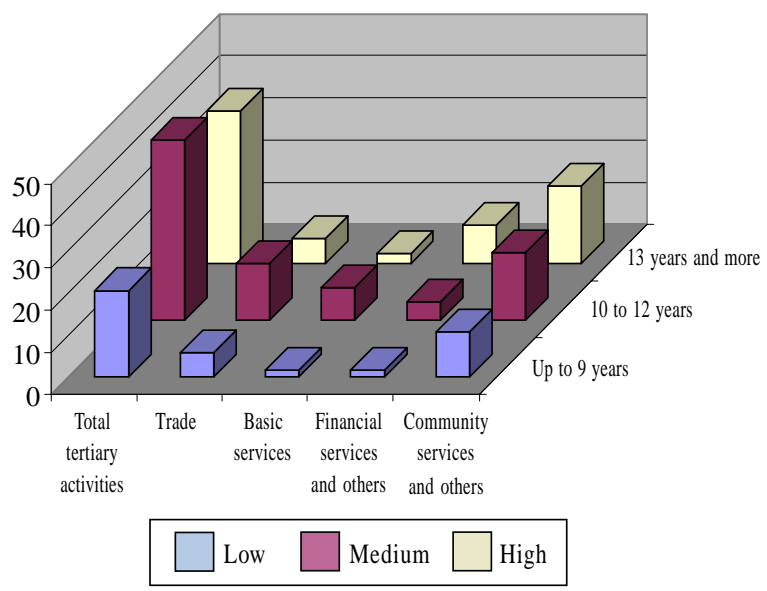

Source: Prepared by the author.

a Simple averages for eight countries.

Tertiary activities shifted the demand for labour towards higher skill levels, either because their organizational or technological characteristics required this or because, as the education level of the active population rose, the most highly qualified people were recruited, even if this was not strictly necessary. The transformation of the tertiary sector was the main reason both for the increase in the number of highly qualified people within the different branches of activity -which was largely responsible for the rise in the proportion of highly qualified people in waged employment- and for the increases resulting from the changes between branches. This contradicts the theory that, thanks to trade liberalization, technological change and investment in machinery and equipment, it was primarily the sectors producing tradable goods that drove modernization and improvements in the quality of the employment structure (Lora and Olivera, 1998, p. 22).

It is generally assumed that there is a high degree of complementarity between capital and skilled labour. Consequently, the tendency for labour demand to shift towards more highly qualified people would be expected to coincide with greater capital-intensiveness $(\mathrm{K} / \mathrm{L})$. Morley (2000), however, did not find that capitalintensiveness had increased in the 1990s. Because the $\mathrm{K} / \mathrm{L}$ ratio is lower in many tertiary activities than in secondary ones (which does not mean that there is not a high ratio in certain branches, particularly basic ser- 
vices), the rise in the demand for well qualified staff was not reflected in greater capital-intensiveness. In manufacturing industry, the trend seen so far has been for the proportion of skilled personnel to increase, although this is largely the result of cuts in less highly skilled staff.

When the same calculation was used to break down the decline in the share accounted for by personnel with relatively low levels of education, i.e., up to 8 or 9 years of schooling, it showed the data available (table 5, part B), that this decline was also due mainly to internal changes in the different branches. Around $80 \%$ of the 4.2 percentage point drop in this group's share of waged employment can be attributed to changes of this type. This shift was largely due to the changing composition of the labour supply (withdrawal of older people with lower levels of education). Most of the fall in wage employment among people with a low level of education as a result of changes within branches was concentrated in tertiary activities; this would seem to be the corollary of the improvement in the employment structure referred to earlier. Changes in manufacturing industry also made a large contribution. Since in this case there were no net increases in the number of highly qualified staff, it would seem that, in many countries, labour force restructuring in this sector during the period analysed mainly meant the shedding of low-skilled staff, unaccompanied by any major process of improvement in the quality of jobs. This bout of employment restructuring seems to have been part of a stage in which companies relied heavily on defensive strategies, with a view to improving competitiveness without major investment (Moguillansky and Bielschowsky, 2000), when generally speaking the qualification levels of human resources are given only a low priority (Palomares and Mertens, 1993).

As regards changes between branches, the decline in the wage employment share of agriculture and manufacturing industry, two of the branches that have traditionally employed mainly low-skilled labour, meant a loss of jobs where this group was concerned. ${ }^{20}$ Meanwhile, despite the bias towards highly qualified people in the labour demand of the tertiary sector, the expansion of some tertiary activities created new jobs for people with a lower level of education as well (figure 5).

Taken all together, developments in the main tradable goods branches, which have traditionally provided much of the wage employment available to people of a lower educational level, must be held responsible for almost half the decline in this group's share of wage employment (particularly because of the fall in the share of these branches in total wage employment), while tertiary activities, which have typically employed less labour from this group, must be held responsible for the other half, owing to the increase in the level of education required of the workforce.

\section{IV}

\section{Tendencies towards heterogeneity and insecurity of employment}

The reforms were expected to make labour markets more homogeneous by reducing wage differentials between workers with different education levels, improving the relative position of small enterprises and microenterprises and boosting formal employment.

\section{Wage differences by education level}

Since labour demand has been shown to have a bias towards more highly qualified personnel, it is not surprising that the data confirm the findings reached by other authors to the effect that wage differentials in most of the countries have recently widened. ${ }^{21}$ In six out of eight countries studied, the difference between the average wage and the pay received by working people with some university education increased to a greater or lesser degree, while the gap between the latter and the wages of a reference group with around eight years of schooling increased by even more (table 6). The only exceptions were Brazil and Costa Rica. This means that differentiated demand for labour more than offset the

\footnotetext{
20 This was not the case in another branch that is a traditional employer of this stratum of the workforce, the construction industry. ${ }^{21}$ See, for example, Robbins (1996) and Lora and Olivera (1998).
} 


\begin{tabular}{|c|c|c|c|c|}
\hline \multirow{3}{*}{ Country and period ${ }^{\mathrm{a}}$} & \multicolumn{4}{|c|}{$\begin{array}{l}\text { Latin America (eight countries): Relative pay } \\
\text { by educational level, 1990s }\end{array}$} \\
\hline & \multicolumn{2}{|c|}{$\begin{array}{l}\text { Pay of those who have attended } \\
\text { university relative to average }\end{array}$} & \multicolumn{2}{|c|}{$\begin{array}{l}\text { Pay of those who have attended university } \\
\text { relative to those with } 7 \text { to } 9 \text { years of education }\end{array}$} \\
\hline & Year 1 & Year 2 & Year 1 & Year 2 \\
\hline Argentina, 1991-1997 & 164.3 & 169.6 & 218.3 & 227.9 \\
\hline Bolivia, 1989-1996 & 235.0 & 292.9 & 251.8 & 506.4 \\
\hline Brazil, 1992-1997 & 380.2 & 383.5 & 553.2 & 553.3 \\
\hline Chile, 1990-1996 & 231.6 & 247.9 & 366.1 & 448.6 \\
\hline Colombia, 1988-1995 & 222.2 & 261.6 & 276.7 & 327.2 \\
\hline Costa Rica, 1990-1996 & 285.0 & 273.2 & 323.1 & 316.7 \\
\hline Mexico, 1991-1997 & 182.1 & 232.1 & 160.1 & 302.2 \\
\hline Peru, 1991-1997 & 220.7 & 275.0 & 321.0 & 403.1 \\
\hline Median & 226.9 & 267.4 & 298.9 & 365.2 \\
\hline
\end{tabular}

Source: Prepared by the author.

a The data are for national totals, except in the case of Argentina (urban areas), Bolivia (departmental capitals and El Alto) and Brazil (six metropolitan areas).

b In Argentina the reference group is those with complete primary education, in Bolivia those with complete intermediate education (basic plus five years) and in Mexico those with complete secondary education (primary plus six years).

impact of the educational improvements in the labour supply which took place during this period.

One factor which reinforced the tendency for differences to widen was minimum wage policy. This was conservative in most of the region's countries, so that a growing gap developed between the real minimum wage and the real average wage in formal companies. ${ }^{22}$ There is also a great deal of evidence to show that wage differences increased in fairly formal, sizeable companies. ${ }^{23}$ This may have been contributed to by the decline in union negotiating power, a tendency that was quite widespread in the region over the last period.

In the countries where wage differences widened, wage earners with lower levels of education received a lower than average share of real wage increases or lost more in cases where wages declined (table 7). The data are not comparable between countries, as they reflect different stages in the economic cycle. In Brazil, for example, real wages began to recover in 1992 after a large drop, and only in 1996 did they return to 1990 levels (ECLAC, 2000b, table VI.4). By contrast, the fall in wages in Mexico largely reflected the impact of the 1994-1995 crisis. Nonetheless, the data given in the table provide an interesting picture of the way the wages received by groups with

${ }^{22}$ For information on changes in average and minimum wages, see ECLAC (2000b and previous years).

${ }^{23}$ See Saavedra (1999) on formal companies in Peru, Ramírez and Núñez (2000) on manufacturing industry in Colombia and Weller (2000) on manufacturing industry in Mexico and formal companies in Chile. different levels of education evolved. In Bolivia and Peru the average wages of the lowest educational groups virtually stagnated, and only the high groups (Bolivia) or the medium and high ones (Peru) saw their pay increase. In Chile, real wages rose for all groups, but here again there were marked differences between different levels of education. It is interesting to note that in these three countries the lowest educational group (0 to 3 years of schooling) did better than the groups immediately above. The reason for this may lie in wage policies, as all three countries raised the minimum wage by more than the average wage in the relevant periods.

As was seen earlier (table 6), in Colombia and Mexico, as in the countries just mentioned, wage differences widened in the periods concerned. In these cases, the cause was a drop in the average wage which affected groups with low levels of education more than those with higher levels. As mentioned earlier, in two countries, Brazil and Costa Rica, wage differentials did not rise. In Brazil, wages rose strongly across the board, while in Costa Rica all strata -with the exception of the group with the least education- received a very small, but evenly spread, rise in real pay.

In conclusion, it can be said that in most of the countries, groups with low and medium-low levels of education shared only to a small extent in wage increases, or lost out more in cases where the general wage situation deteriorated. In some cases, active wage policies seem to have mitigated this tendency for the group with the least schooling. 
TABLE 7

Latin America (seven countries): Annual change in real pay by educational level, 1990 s

(Percentages)

\begin{tabular}{|c|c|c|c|c|c|c|c|}
\hline \multirow[t]{2}{*}{ Country and period ${ }^{\mathrm{a}}$} & \multicolumn{7}{|c|}{ Years of study ${ }^{b}$} \\
\hline & 0 to 3 & 4 to 6 & 7 to 9 & 10 to 12 & 13 to 15 & 16 and over & Total \\
\hline Bolivia, 1989-1996 & 0.6 & -0.1 & -0.8 & 1.0 & 8.0 & 5.6 & 3.2 \\
\hline Brazil, 1992-1997 & 5.6 & 6.2 & 7.6 & 6.4 & 5.4 & 7.6 & 7.4 \\
\hline Chile, 1990-1996 & 3.3 & 1.1 & 2.0 & 3.7 & 4.1 & 5.5 & 4.3 \\
\hline Colombia, 1988-1995 & -5.8 & -2.9 & -1.3 & -0.8 & 0.1 & 1.1 & -1.3 \\
\hline Costa Rica, 1990-1996 & -0.7 & 0.7 & 1.0 & 1.0 & 1.0 & 0.6 & 1.3 \\
\hline Mexico, 1991-1997 & -7.4 & -6.4 & -10.6 & -2.7 & \multicolumn{2}{|c|}{-1.3} & -5.3 \\
\hline Peru, 1991-1997 & 1.1 & -1.3 & 3.1 & 2.7 & 4.3 & 7.1 & 3.2 \\
\hline
\end{tabular}

Source: Prepared by the author.

a The data are for national totals, except in the case of Argentina (urban areas), Bolivia (departmental capitals and El Alto) and Brazil (six metropolitan areas).

b The categories for Bolivia are: i) incomplete basic and less; ii) complete basic; iii) up to complete intermediate; iv) middle and middle technical; v) college of education, incomplete higher technical, incomplete university; vi) complete higher technical and complete university. The categories for Chile are: up to 3 years, from 4 to 7,8 , from 9 to $11,12,13$ and over.

\section{The difference between microenterprises and larger firms}

In the 1980 s, real wages generally fell by more in the formal sector than in microenterprises, so that wage differences between the two types of firm tended to decline (table 8).

In the 1990s, wage differences between microenterprises and formal companies apparently began to increase again in most of the countries (table 8). What seems to underlie this tendency is the strategy followed by many larger firms of reducing employment to lower costs, as this, in a context of substantial productivity growth, led to wages rising in formal activities. By contrast, microenterprises created a large proportion of all new jobs, but had little scope for improving working conditions, and more specifically wages.

Despite the increase in the wage differential between microenterprises and larger companies (which reflects a widening productivity gap), activities requiring appreciable levels of skill have also been developed in smaller units. This shows that the growth of microenterprise has not been based solely on the proliferation of survival units, but that very small establishments with a far from negligible level of technology and human capital have come into being, and these are benefiting from the opportunities being opened up by new technologies for smaller enterprises (Weller, 2000, section 6.D).

\section{Wage differences between men and women}

In all the countries studied there is a wage differential between men and women, both at the different educa- tional levels and overall. During the 1990s this difference fell in all the countries (table 9). In some cases (Bolivia, Colombia and Mexico) this result was partly due to a large influx of highly educated women into the labour force, leading to a rise in educational standards among the female workforce that not only outstripped the corresponding rise among men, but also reinforced the tendency for highly educated women to account for a larger proportion of female wage employment than highly educated men of male wage employment. This difference is largely accounted for by the difficulties that are faced by many less well educated women, who generally have fewer economic resources, if they wish to work for a wage, particularly if they are mothers. ${ }^{24}$ The disproportionate expansion of employment in tertiary activities was a factor that encouraged the entry of highly educated women into the labour market. ${ }^{25}$ Their participation in these branches has traditionally been above the average, and during the 1990s it increased yet further in many countries. Furthermore, the growth of

\footnotetext{
${ }^{24}$ Because of this, labour force participation tends to be much more sharply polarized between women of low and high educational levels and economic strata than in the case of men; see Jiménez and Ruedi (1998).

${ }^{25}$ See ECLAC (1998) and Marinakis (1999). Although the proportion of women working in the informal sector is higher than that of men, the shift towards informal working in the 1990s affected women slightly less: between 1990 and 1998 the percentage of women working in the informal sector in urban areas rose from $49.2 \%$ to $52.0 \%$, while for men the proportions were $41.1 \%$ and $45.0 \%$ (ILO, 1999a, p. 58).
} 
TABLE 8

Latin America (seven countries): Ratio between wages of workers in companies of different sizes, urban areas, 1980s and 1990s

\begin{tabular}{|c|c|c|c|c|}
\hline \multirow[t]{2}{*}{ Country } & \multirow[t]{2}{*}{$\begin{array}{c}\text { Period (first year, intermediate } \\
\text { year and last year) }\end{array}$} & \multicolumn{3}{|c|}{$\begin{array}{c}\text { Ratio between the wages of non-professional, non-technical } \\
\text { workers in establishments of up to } 5 \text { people and in } \\
\text { those of more than } 5 \text { people }\end{array}$} \\
\hline & & $1980 \mathrm{~s}$ & Early $1990 \mathrm{~s}$ & Mid-1990s \\
\hline Argentina $^{\mathrm{a}}$ & 1980-1990-n.d. & 1.3 & 1.3 & n.d. \\
\hline Bolivia & 1989-1992-1997 & 1.4 & 1.2 & 1.4 \\
\hline Brazil $^{b}$ & 1979-1990-1996 & 1.6 & 1.4 & 1.6 \\
\hline Chile $^{\mathrm{a}}$ & n.d.-1992-1996 & n.d. & 1.3 & 1.7 \\
\hline Costa Rica & 1981-1990-1997 & 1.5 & 1.4 & 1.5 \\
\hline Mexico $^{\mathrm{ac}}$ & n.d.-1991-1997 & n.d. & 1.7 & 2.3 \\
\hline Peru $^{c}$ & 1985-1994-1997 & 2.1 & 2.0 & 2.3 \\
\hline
\end{tabular}

Source: Prepared by the author on the basis of ECLAC (several years).

a Includes public-sector wage earners.

b The comparison is between the average wages of workers with and without employment contracts.

c Includes professional and technical workers, national total.

TABLE 9

Latin America (eight countries): Changes in the position of women in the workforce, by qualification level and relative pay, $1990 \mathrm{~s}^{\mathrm{a}}$

\begin{tabular}{|c|c|c|c|c|c|c|c|}
\hline \multirow[t]{2}{*}{ Country and period } & \multicolumn{2}{|c|}{$\begin{array}{c}\text { Share of waged female } \\
\text { employment held by } \\
\text { women who have } \\
\text { attended university }\end{array}$} & \multicolumn{2}{|c|}{$\begin{array}{c}\text { Male/female wage } \\
(\%)\end{array}$} & \multicolumn{3}{|c|}{$\begin{array}{c}\text { Change in the male/female wage } \\
\text { difference between year } 1 \text { and } \\
\text { year } 2(\%)\end{array}$} \\
\hline & Year 1 & Year 2 & Year 1 & Year 2 & $\begin{array}{l}\text { 4-6 years of } \\
\text { education }\end{array}$ & $\begin{array}{l}\text { 7-9 years of } \\
\text { education }\end{array}$ & $\begin{array}{l}16 \text { years } \\
\text { and more }\end{array}$ \\
\hline Bolivia, 1989-1996 & 17.9 & 23.0 & 137.3 & 125.0 & n.d. & n.d. & n.d. \\
\hline Brazil, 1992-1997 & 16.9 & 18.1 & 140.9 & 128.2 & -13.5 & -4.4 & -13.3 \\
\hline Chile, 1992-1996 & 34.6 & 34.7 & 132.8 & 127.5 & -17.6 & +3.1 & -8.2 \\
\hline Colombia, 1988-1995 & 14.8 & 18.8 & 167.6 & 133.1 & -23.6 & +9.2 & -10.4 \\
\hline Costa Rica, 1990-1996 & 18.3 & 23.3 & 121.6 & 120.8 & +0.5 & -4.9 & -17.2 \\
\hline Mexico, 1991-1997 & 14.6 & 19.2 & 137.5 & 121.6 & -8.8 & -14.1 & +2.0 \\
\hline Peru, 1991-1997 & 33.5 & 32.2 & 132.3 & 132.4 & -5.1 & +11.6 & -20.6 \\
\hline
\end{tabular}

Source: Prepared by the author.

a The data are for national totals, with the exception of Bolivia (departmental capitals and El Alto) and Brazil (six metropolitan areas).

employment in these branches was accompanied by substantial improvements in skill levels.

Apart from the fact that women's educational level increased by more than men's, the narrowing of wage differentials between the sexes at certain levels of education also appears to have contributed in some degree to the positive trend overall. Indeed, the differential between male and female wage earners who have completed university studies, which is usually the largest, generally tended to narrow in Brazil, Colombia, Costa Rica, Chile and Peru; only in Mexico did it rise slightly. A similar situation is found among wage earners with four to six years of schooling. By contrast, there was a less homogeneous trend in wage differentials between men and women with around eight years of schooling, as these increased in Colombia, Chile and Peru and fell in Brazil, Costa Rica and Mexico.

\section{The quality of wage employment}

Those who analyse the labour market situation in Latin America and the Caribbean are aware that it is not enough just to measure the quantity of jobs generated; there are problems of quality which cannot be over- 
looked. These arise partly because many jobs are created in response to the pressure of labour supply, which forces many economically active people to accept poor working conditions as long as they can obtain an income. Other problems derive from the characteristics of demand (low levels of technology entailing low productivity) and the institutional conditions obtaining in the labour market (low levels of social protection or non-compliance with regulations).

Although surveys dealing with changes in the labour market do not all use the same indicators, the information available would seem to indicate a downward trend in quality, in terms of job stability and social security (table 10). ${ }^{26}$ In a number of countries (Argentina, Bolivia, Brazil, Chile, Colombia) there was a fall in the number of indefinite contracts or even of wage employment with contracts; in others (Mexico, Peru) social security coverage is found to have declined. ${ }^{27}$ The deterioration in the average quality of wage employment affected both men and women, so that the differences in employment quality between the two sexes were maintained. This deterioration was partly due to the introduction of greater flexibility into the institutional arrangements governing the labour market, the aim of which was to cope with the new market conditions (Weller, 2000, chapter 7).

26 For a detailed conceptual and empirical analysis of employment quality, see Infante (1999), and for trends in different employment quality indicators, see ECLAC (2000b, statistical annex); regarding social security affiliation, see ILO (1999a, pp. 63 ff.).

27 See also Tokman and Martínez (eds.) (1999).
TABLE 10

Latin America (eight countries): Indicators of waged employment quality, 1990s

\begin{tabular}{|c|c|c|c|}
\hline Country and periods ${ }^{a}$ & Indicator & Year 1 & Year 2 \\
\hline \multirow[t]{3}{*}{ Argentina, 1991-1997 } & Registered & 63.2 & 58.8 \\
\hline & - men & 68.8 & 62.7 \\
\hline & - women & 55.7 & 53.1 \\
\hline \multirow[t]{3}{*}{ Bolivia, 1989-1996 } & Permanent contract & 78.8 & 76.7 \\
\hline & - men & 76.0 & 74.4 \\
\hline & - women & 86.5 & 81.7 \\
\hline \multirow[t]{3}{*}{ Brazil, 1992-1997 } & With carteira & 68.8 & 64.7 \\
\hline & - men & 71.5 & 67.0 \\
\hline & - women & 64.5 & 62.9 \\
\hline \multirow[t]{3}{*}{ Chile, 1990-1996 } & With contract & 82.0 & 76.1 \\
\hline & - men & 82.4 & 77.5 \\
\hline & - women & 81.0 & 73.4 \\
\hline Colombia, 1991-1997 & Permanent work & 81.8 & 78.9 \\
\hline \multirow[t]{3}{*}{ Costa Rica, 1990-1996c } & High quality & 55.6 & 42.6 \\
\hline & - men & 56.0 & 46.5 \\
\hline & - women & 54.7 & 34.3 \\
\hline Mexico, 1990-1997 & With benefits & 79.5 & 75.3 \\
\hline \multirow[t]{3}{*}{ Peru, $1991-1997^{d}$} & With social security & 51.2 & 26.9 \\
\hline & - men & 52.0 & 26.7 \\
\hline & - women & 49.4 & 27.4 \\
\hline
\end{tabular}

Source: Prepared by the author.

a The data are for national totals, with the exception of Argentina (urban areas), Bolivia (departmental capitals and El Alto), Brazil (six metropolitan areas) and Colombia (seven metropolitan areas).

b Total of those in work.

c Employment quality in Costa Rica was measured using an indicator that took into account compliance with the minimum wage law, social security affiliation and employment stability (see Montiel, 1999).

d Only private-sector wage earners.

\section{$\mathrm{V}$}

\section{Conclusions and outlook}

The labour problems of the 1990s were due not to jobless growth but to weak economic growth compounded by reduced labour-intensiveness, mainly owing to transformations in tradable goods-producing activities. The demand for labour was thus restrained, while pressure from the supply side generated a high proportion of non-wage employment. This was not enough to make up for the shortage of new wage employment, so unemployment followed a rising trend to the point where, by the end of the decade, it had reached levels even higher than those seen during the debt crisis of the 1980s. The effects of the economic reforms were contradictory and unexpected: while they stimulated growth, and thus the demand for labour, they reduced labour-intensiveness.

Nor were expectations about sectoral developments in the quantity and characteristics of employment met. Modernization of production methods in companies in many branches, and sectoral restructuring that gave greater weight to tertiary activities, contributed to greater segmentation of the labour market on the basis of educational level, with the demand for labour showing a 
clear preference for people with medium and high levels of education. As a result, people with less formal schooling had less access to wage employment and the wage difference between skilled and unskilled workers grew. The gap between microenterprises and bigger firms also increased and, as employment conditions became more flexible, employment quality indicators tended to worsen. All these tendencies went against the expectations vested in the reforms. The only exception to the trend towards polarization seen in the region's labour markets was the narrowing of the wage gap between men and women.

Sectoral restructuring of employment helped trigger a movement towards greater heterogeneity in the labour market. On the one hand, strong job creation took place at the top and bottom of the labour market simultaneously: while educational expectations increased and the demand for highly qualified staff grew, most new employment was actually created in lower-quality segments (informal sector). At the same time, the differences in average labour productivity and wages between microenterprises and larger firms increased, which seems to suggest that the gap between the formal and informal sectors is growing. Meanwhile, within the formal sector itself (medium-sized and large enterprises), working conditions can be seen to have become more heterogeneous, in terms both of earnings (increase in wage differences between staff with different qualification levels) and employment conditions (emergence of a divide between stable cores of workers and workers whose employment is unstable, with less secure types of contract and lower social protection). Lastly, differences have increased within the microenterprise and own-account sectors, as there is a segment of these where the employment structure is also tending to improve.

What is the outlook for labour demand and job creation at the sectoral level? The performance of the agricultural sector during the 1990s, and international experience, do not give grounds for thinking that the net negative balance of job creation is something temporary. Although new agricultural jobs will be created as crops are diversified and certain activities expanded, the characteristics of factor utilization in many dynamic activities, and the moderate growth of these, mean that there will not be many of them. Most importantly, in the majority of the region's countries much of the rural and agricultural population belongs to the poorest strata, and a great many agricultural workers can be placed in the categories of visible underemployment (seasonal work) or invisible underemployment. This means that the forces driving labour out of agriculture (particularly young people) and into non-agricultural activities are still operating; indeed, this is a worldwide trend of long standing. In most of the countries, any reversal of this trend, i.e. any increase in net agricultural employment, would be rather a manifestation of the weakness of non-agricultural sectors and the factors that make them attractive to labour than a reflection of any rise in productive employment opportunities in the agricultural sector. Progress in overcoming the problems typically affecting small-scale farming, both in actual agricultural production and in the conditions under which this is undertaken, would raise labour productivity and incomes rather than direct employment in the sector. Owing to the many linkages that would come into play, however, a transformation of this kind in the agricultural sector would have a positive effect on rural employment in other sectors.

As regards the prospects for manufacturing employment, there are grounds for hoping that in future the sector will not be characterized by jobless growth. It would seem that with the completion of the restructuring phase, during which many companies shut down while others concentrated on defensive, labour-reducing measures, many countries have left the severest and most immediate of the negative effects behind them. Improvements in productivity and competitiveness mean that many companies will be able to compete more successfully in domestic and external markets. Thus, provided the macroeconomic problems can be solved, sectoral production should be able to grow at reasonable rates, with favourable effects on employment. This is true both for the biggest firms and for small and medium-sized ones, which are generally more labour-intensive and prosper during periods of expansion.

On the other hand, global competition and the trend towards greater use of labour-saving technologies mean that the sector cannot return to being the engine of job creation that it was up until the 1970 s. Competition, increasingly on a world scale, is limiting the prospects for growth in labour-intensive areas, while in others it will put steady pressure on companies to choose "first best" solutions that increasingly reduce the scope for adopting other combinations of factors. This being the case, the job creation rate of the sector will be moderate, and across the region its share of employment will continue to decline. ${ }^{28}$ This process will be slower in

\footnotetext{
28 This would be consistent with developments in the industrialized countries, and also in the East Asian "tigers"; see Rowthorn and Ramaswamy (1997).
} 
the region northern countries because of the opportunities for industrial employment and investment flowing from increasing integration with the North American markets.

Given this background, it seems clear that in the future too the great bulk of new jobs will have to come from tertiary activities. The relative expansion of both output and employment in this sector is a long-term global trend. The issue here is not just that the primary and secondary sectors are generating few jobs, but that tertiary activities seem to be called upon to play a new role in the economic structure. Furthermore, the competitiveness of the sectors that have been the traditional producers of tradable goods is also coming to depend more and more on efficient integration with services of many kinds, such as technological research and development, financial and marketing systems and after-sales services. Other areas that are important to systemic competitiveness, albeit indirectly, and that are tending to expand and generate good-quality employment on a substantial scale, are education and health care. If the socio-economic structure as a whole is to be modernized, the tertiary sector needs to play a more prominent role, particularly in the field of knowledge, and to generate the appropriate employment for people with medium and high qualifications. However, the transformations now under way may also generate large numbers of tertiary jobs for people with intermediate and low levels of education, particularly in community and personal services, trade and the hotel industry, and certain business services (cleaning, catering, transport, waste treatment, etc.).

The transformations now going on complicate analysis of sectoral developments in employment, since many of the measuring instruments traditionally used are no longer so effective in capturing their effects. In sectoral analysis, the distinction between the primary, secondary and tertiary sectors is becoming increasingly blurred, and this is weakening labour market research based on the surveys commonly used. Changes to the production structure of economies and the organization of companies are having corresponding effects on the structure of employment. In many manufacturing companies, for example, we are seeing a rise in the proportion of jobs that are not directly linked with production, such as research, internal services and customer services. By contrast, the tendency for certain activities to be outsourced may lead to a statistical reduction in employee numbers and affect average labour productivity in companies that do this, even if there has been no transformation in production processes.
These processes do not just affect the measurement of employment and productivity by branches of activity; they also influence other labour measurement and analysis variables such as company size and occupational category. For example, subcontracting of individuals or services may transform the composition of occupational categories by turning the wage earners of big companies into wage earners in small or mediumsized enterprises, or into own-account workers.

In the same way, the breakdown and recomposition of production processes is leading to a production -and labour-structure that is much more heterogeneous than the old one. Specifically, the effects on job creation and employment characteristics of replacing vertically organized production processes in large companies with networks or chains that have multiple links to local and, increasingly, foreign suppliers of inputs of every kind (goods and services) are little understood in terms of their extent and characteristics, but are certainly far-reaching.

While the tendencies referred to are changing the outlook for the sectoral composition of employment in future, economic growth is the main factor underlying the level of demand for labour, and thus the relative weight of the different sectors of the labour market that are driven by demand and by supply. When economic growth is inadequate, a high percentage of tertiary employment is concentrated in informal occupations. Thus, any policy that aims to improve the labour market has to concern itself with the level and stability of this growth. Meanwhile, long-term labour market problems and the tendency for labour-intensiveness to fall mean there is a need to design instruments that can foster competitive production and the creation of productive employment simultaneously over the medium term. ${ }^{29}$

The tendency for wage differences to increase is likely to weaken gradually in future as the supply of labour grows in those occupations where it is currently outstripped by demand. Considering, though, that the new production norms require more intensive use of technology and human capital than the Taylorist system that has operated since the early post-war years, and that the demand for low-skilled labour would appear to be limited, there are no grounds for expecting large reductions in wage differences in the near future. Other important aspects are the forces at work in the

\footnotetext{
${ }^{29}$ See Altenburg, Qualmann and Weller (1999) for a discussion of measures to foster productive employment in different areas of production, along with complementary policies.
} 
institutional sphere of the labour market, including the future role of unions, which generally have an equalizing effect on the wage structure, and minimum wage policies, which have been conservative in most of the countries, but in others have raised the wage floor for less educated workers.

\section{Bibliography}

Altenburg, T., R. Qualmann and J. Weller (1999): Wirtschaftliche Modernisierung und Beschäftigung in Lateinamerika. Zielkonflikte und Lösungsansätze, Berlin, Deutsches Institut für Entwicklungspolitik.

Berman, E., J. Bound and Z. Griliches (1994): Changes in the demand for skilled labor within U.S. manfacturing: Evidence from the annual survey of manufactures, The Quarterly Journal of Economics, vol. CIX, issue 2, No. 436, Cambridge, Massachusetts, Harvard University.

Duryea, S. and M. Szèkely (1998): Labor markets in Latin America: A supply-side story, paper presented at the seminar Employment in Latin America: What is the Problem and How to Address It?, Cartagena de Indias, Inter-American Development Bank (IDB), 15 March.

ECLAC (Economic Commission for Latin America and the Caribbean)/CELADE (Latin American Demographic Centre) (1999): Latin America: Urban and Rural Population. Projections 1970-2025, Demographic bulletin, year 32, No. 63, Santiago, Chile.

ECLAC (several years): Social Panorama of Latin America, Santiago, Chile.

(1997): The Equity Gap. Latin America, the Caribbean and the Social Summit, LC/G.1954/Rev.1-P, Santiago, Chile. United Nations publication, Sales No. E.97.II.G.11.

(1998): Social Panorama of Latin America, 1997, LC/G.1982-P, Santiago, Chile.

(2000a): Social Panorama of Latin America, 19992000, LC/G.2068-P, Santiago, Chile.

(2000b): Economic Survey of Latin America and the Caribbean, 1999-2000, Santiago, Chile.

IDB (1997): Economic and Social Progress in Latin America. 1997 Report, Washington, D.C.

ILO (International Labour Organization) (1998a): Yearbook of Labour Statistics, Geneva.

(1998b): Panorama laboral '98, Lima.

(1999a): Panorama laboral '99, Lima.

(1999b): Trabajo decente y protección para todos. Prioridad de las Américas, memoria del Director General, XIV Reunión Regional Americana, Lima, 24-27 August.

Infante, R. (ed.) (1999): La calidad del empleo. La experiencia de los países latinoamericanos y de los Estados Unidos, Santiago, Chile, ILO.

Jiménez, L.F. and N. Ruedi (1998): Determinantes de la desigualdad entre los hogares urbanos, Revista de la CEPAL, No. 66, LC/G.2049-P, Santiago, Chile, ECLAC.

Katz, J. M. (2000): Reformas estructurales, productividad y conducta tecnológica en América Latina, Santiago, Chile, ECLAC.

Lora, E. and M. Olivera (1998): Macro policy and employ- ment problems in Latin America, paper presented at the seminar Employment in Latin America: What is the Problem and How to Address It?, Cartagena de Indias, IDB, 15 March.

Marinakis, A.E. (1999): Género, pobreza y empleo en los países del Cono Sur: interrelaciones y estado de situación, Santiago, Chile, ILO, Multidisciplinary Technical Team.

Moguillansky, G. and R. Bielschowsky (2000): Las reformas económicas y la inversión en América Latina: un enfoque sectorial, Santiago, Chile, ECLAC.

Montiel Masís, N. (1999): Costa Rica: reformas económicas, sectores dinámicos y calidad de los empleos, serie Reformas económicas series, No. 26, Santiago, Chile, ECLAC.

Morley, S.A. (2000): The Income Distribution Problem in Latin America, Washington, D.C., The Brookings Institution.

Morley, S.A., R. Machado and S. Pettinato (1999): Indexes of Structural Reform in Latin America, Reformas económicas series, No. 12, Santiago, Chile, ECLAC.

Palomares, L. and L. Mertens (1993): Cambios en la gestión y actitud empresarial en América Latina. Un marco de análisis, Revista de economía y trabajo, year 1, No. 2, Santiago, Chile, Programa de Economía del Trabajo (PET).

Porter, M.E. (1990): The Competitive Advantage of Nations, New York, The Free Press.

PREALC (Regional Employment Programme for Latin America and the Caribbean) (1991): Empleo y equidad: el desafio de los 90, Santiago, Chile.

Psacharopoulos, G. and Y.C. Ng (1992): Earnings and Education in Latin America, Assessing Priorities for Schooling Investments, The World Bank, Policy Research Working Papers, No. 1056, Washingon, D.C., World Bank.

Ramírez, J.M. and L. Núñez (2000): Reformas, crecimiento, progreso técnico y empleo en Colombia, Reformas económicas series, No. 59, Santiago, Chile, ECLAC.

Robbins, D.J. (1994): Relative wage structure in Chile, 19571992: Changes in the structure of demand for schooling, Estudios de economía, vol. 21, special issue, Santiago, Chile, University of Chile, Department of Economics. (1996): Evidence on Trade and Wages in the Developing World, Technical papers, No. 119, Paris, OECD Development Centre.

Rowthorn, R. and R. Ramaswamy (1997): Deindustrialization: It's Causes and Implications, Economic issues, No. 10, Washington, D.C., International Monetary Fund (IMF).

Saavedra Chanduví, J. (1999): La dinámica del mercado de trabajo en el Perú antes y después de las reformas 
estructurales, Reformas económicas series, No. 27, Santiago, Chile, EClAC.

Stallings, B. and W. Peres (2000): Growth, Employment, and Equity. The Impact of the Economic Reforms in Latin America and the Caribbean, Santiago, Chile, ECLAC/Fondo de Cultura Económica (FCE).

Thomas, J. (1997): El nuevo modelo económico y los mercados laborales en América Latina, V. Bulmer-Thomas (comp.), El nuevo modelo económico en América Latina. Su efecto en la distribución del ingreso y la pobreza, Mexico City, FCE.

Tokman, V. E. and D. Martínez (eds.) (1999): Flexibilización en el margen: La reforma del contrato de trabajo, Geneva, ILO.
Weeks, J. (1999): Salarios, empleo y derechos de los trabajadores en América Latina entre 1970 y 1998, Revista internacional del trabajo, vol. 118, No. 2, Geneva, International Labour Organization (ILO).

Weller, J. (2000): Reformas económicas, crecimiento y empleo: los mercados de trabajo en América Latina, Santiago, Chile, ECLAC/FCE.

Wood, A. (1997): Openness and wage inequality in developing countries: The Latin American challenge to East Asian conventional wisdom, The World Bank Economic Review, vol. 11, No. 1, Washington, D.C., World Bank. 